\title{
Role of Dietitian in a Food Service Industry
}

\author{
Zainab Hussain* \\ Food Service Dietitian at SFC, Tabba Heart Institute (THI), Pakistan
}

Submission: August 19, 2017; Published: September 13, 2017

*Corresponding author: Zainab Hussain, Diet Consultant at Safe Food Caterers (SFC), Tabba Heart Institute, Pakistan, Email: zainabhussain874@gmail.com

\section{Opinion}

Food service is a multinational operation often described as a system transforming inputs (human labor and skills, materials, facilities) to outputs (meal, customer satisfaction, fianantional accountability). Food service is an increasingly complex context, which will always be in a process of change as new demands occur and vary from country to country. As food and meals for vulnerable groups must be nutritious (for prevention or treatment) and tailored for specific individuals and groups, as well as being tasty, tempting and familiar they must be safe, sustainable and financially reasonable, there is a need of a person to look after all these aspects and that person is the 'Dietitian'.

A dietitian has numerous roles to play. After clearing the registered dietitian/ nutritionist (RDN), she is able to use her strengths to teach others about the importance of healthy eating and good nutrition.

RDNs are no longer bound to clinical side, but they are considered as a valuable team member for implementing their skills in the food service too, they are also engaged in cafeterias and sports and entertainment areas. They can also peruse their career in pharmaceutical companies to promote and market better food and nutritional products in a business setting. A dietitian who has responsibility within food service management, for providing nutritionally adequate, safe, tasty, and sustainable quality food to individuals or groups to improve health and treat disease within financial and regulatory frameworks. Food service dietitians can work in institutional, community and educational settings and other work places including food industry.

The role of the food services dietitian is not just rising, it's evolving and expanding. RDNs are valued because their skills are essential to the current food service environment. They play a key role in operations that provide meals for various target groups and settings, in fostering health, wellness and sustainability trends that clients and consumers demand today. Their knowledge is integral for complying with government regulations, collaborating with chefs on recipe and menu developing.

According to Brand Settler (first food service nutritionist) "The RDN's role is to help bridge the gap for patients and customers about the better options in their meal." They have a central role in initiating and formulating documents of visions, strategies, policies and guidelines for food service settings, based on steering documents from e.g. WHO, EU and member states. Moreover dietitians working in food service settings play a key role in transforming theory in those documents to practice in collaboration with inter professional teams in everyday work.

RDN's play a critical role in providing education about healthy eating. They do so by tasting meals, cooking demonstrations, health food service operations to ensure cost effective production to nutrition, safety, sanitation and quality standards. They may be involved in developing policies for food service to in health promotion and disease control. Dietitians are also expanding their skills beyond analyzing recipes and reviewing menus. They are playing vital roles in recipe and product development. They are developing their management skills and being promoted into higher level positions. They are becoming more involved in operations and marketing.

Dietitians can play varied roles, e.g.: i) to consult ii) to manage or iii) to direct the food service operations. Being diet consultants, one requires expertise in such diverse topics as menu planning, special diets, food safety, sustainability, purchasing \& procurement and kitchen design and redesign as well as education and communication. Being diet managers, one may require all the previous skills in addition to the responsibility of managing the food service operation and being a director of food services, one will have an overall responsibility for several foodservice operations including all the responsibilities related to that role.

The sky is the limit for dietitians in food service. For one reason being that RDNs have evolved over the years with 
consumer health demand. Health and wellness is a consumer food trend that is not going away anytime soon. As a result, the expertise of the dietitian will only continue to be valued more.

As a personal experience of foodservice dietitian, my major involvement is to look after the patient's meal tray dispatches according to their demands and clinical requirements. I also document the inpatients meal service evaluation form after sensory evaluation of the prepared food as well as maintain the record of meal served. I enforce good working conditions and relationship with the hospital's staff and try to create facilitating zone within the premises. I also resolve patient tray line issues and matters on day to day basis like product monitoring, quality, specifications and hygiene related issues. Moreover, I have to monitor and supervise the staff and managers with all the activities performed in all my departments. I carry out multi-tasks in my area of all food and beverage related issues and if required, issue guidelines from time to time to the staff for good manufacturing practices. I also have to utilize expert knowledge of nutrition and dietetics and food service system together to advocate effective patient meal service which meets patient's demands and is cost effective.

\section{Your next submission with Juniper Publishers will reach you the below assets}

- Quality Editorial service

- Swift Peer Review

- Reprints availability

- E-prints Service

- Manuscript Podcast for convenient understanding

- Global attainment for your research

- Manuscript accessibility in different formats

( Pdf, E-pub, Full Text, Audio)

- Unceasing customer service

Track the below URL for one-step submission https://juniperpublishers.com/online-submission.php 